there is need for a stronger editorial hand. What is an excellent analysis of the state of multiculturalism in the introduction appears in short form in most of the subsequent chapters in a way that seems unnecessarily repetitive. Finally, while the diversity and inclusivity prioritized in this volume is important, the chapters do not hang together as well as one would like. Such issues notwithstanding, the ideas presented in this collection should be taken up and engaged by Left History readers who are invested in leftist political critique in Canada.

\author{
Megan Harvey \\ University of Victoria
}

\title{
Adrienne Shadd, The Journey from Tollgate to Parkway: African Canadians in Hamilton (Toronto: Dundurn, 2010).
}

\section{The Journey from Tollgate to Parkway: African Canadians in Hamilton by Adrienne}

Shadd explores a city quite familiar to historians of Ontario. This book, however, is an attempt to move the experiences of African Canadians from the footnotes to the centre of historical scholarship (20). The title reflects the symbolic journey of the city's Black community from when Julia Berry was the wellknown operator of the tollbooth around the mountain in the 1880 s, to the naming of the Lincoln Alexander Parkway in 1997 in honour of the country's first Black MP. From the first known Blacks in the province to present-day activists, the reader is introduced to hundreds of Hamilton's African Canadian women and men in a intriguing study of labour, community, and social change.

The first five of eight chapters cover the period prior to the twentieth century. Shadd's meticulous research of this early period is this study's most compelling feature. The discussion begins in the Eighteenth-century with a thorough examination of slavery in Upper Canada. The complexities of emancipation are revealed through a balanced analysis of the lives of both enslaved people and the colonial elite, particularly slave owners. A combination of published advertisements, reports of rebellion, official government records, and slave narratives are used to uncover the gradual move towards the Emancipation Act of 1833.

The period from 1833 to the turn of the century is discussed through highlighting the diverse experiences and circumstances of Blacks in Hamilton. Shadd effectively challenges the dominant narrative that the Black population in the nineteenth century was made up almost entirely of fugitive slaves who escaped through the Underground Railroad. She features prominently the stories of Blacks who had lived in freedom in the United States before arriving in 
Canada.

Shadd's diligent use of the mid-century census is most impressive through her discussion of the origins of Hamilton's Black population, which even in the 1850s was made up of 41 percent Canadian-born (131). The census is also used to discuss the working lives of nineteenth-century Blacks. The reader becomes acquainted with the various skilled and 'unskilled' workers in the most common occupations of barber, waiter, driver, washer, domestic servant, and porter, along with the few individuals who ran successful businesses and saloons.

Issues related to access to education and institution building are also brought up in the discussion of the nineteenth-century experience. The struggle for de-segregated public schools, and the important role of the African Methodist Episcopal and Baptist churches, are examined as key issues throughout the nineteenth and twentieth centuries. The strategies used by individuals, as well as formal and informal groups to fight for equal access to education, employment, service, and politics are highlighted in great detail. Labour continues to be a key topic in the discussion of the twentieth century. The campaign for equal hiring in the local fire department, the significance of the exclusively Black occupation of railway porters during the Depression, and the increased opportunities available during World War II, are a few of the topics explored.

The most notable omission in this thorough study is the role of integrated churches. While the AME and Baptist Church are rightfully identified as centres of faith, community, and activism throughout the nineteenth and twentieth centuries, Shadd excludes from her discussion the significance that religion had in the lives of those who chose to be part of integrated church communities. Historians of Ontario's religious history will note that Rev. Geddes' Anglican Church in Hamilton is one of the earliest in the province to promote integration in the middle of the nineteenth century, yet the topic is a surprising, and disappointing omission from this local study.

Exposing the complexities and diversity of historically marginalized individuals and communities is no simple task for even the most experienced historian. Shadd is to be applauded for her ability to weave exhaustive quantitative research with oral testimonies, photographs, obituaries, advertisements, government records, petitions and various other published and unpublished sources. This is a readable book for those with little historical background, yet it introduces even the most widely read historian to individuals, events, and institutions that helped shape Hamilton. 


\section{Lina Sunseri, Being Again of One Mind: Oneida Women and the Struggle for Decolonization (Vancouver: UBC Press, 2011).}

Lina Sunseri's book Being Again of One Mind is an eloquent blend of a personal and professional research agenda. Influenced greatly by her Oneida heritage and community, Sunseri tests our notions of mainstream theories concerning nationalism and decolonization by presenting the unique perspectives of Oneida women. Based on the interviews of roughly twenty members of the Oneida of the Thames (one of three communities that constitute the modern Oneida nation) the author's work provides material to answer questions concerning the impact of colonization on the status and power of Aboriginal women. More specifically her aim is to "examine the process of decolonization," arguing, "a decolonizing nationalist movement has the potential to restore the gender balance that existed in [the Oneida] nation prior to colonialism (2)."

This so-called "alterNative" analysis explores the Oneida colonial experience by emphasizing themes relevant to many indigenous histories. At the forefront are healing and cultural rejuvenation, bolstered by the actions of community women. For centuries Oneida women, much like other mother-centered First Nations, have held a powerful place within their society. Before European encounters women chose political leaders, called men to war and exerted authority over land and homes. This system of power was transformed in the wake of colonial regimes; yet, Sunseri demonstrates that it did not disappear entirely. Rather than focusing on the loss of power among Oneida women Sunseri gives a hopeful analysis suggesting ways in which women are able to regain their former influence and responsibilities through nationalist movements.

By drawing upon the perspectives of Oneida women, Sunseri broadens our understanding of "nation." Outside the perimeters of Eurocentric notions of nations and states, the author re-conceptualizes these social constructs in Oneida terms. Lori, one of the interviewees, for instance, describes "nation" as synonymous with Oneida, an identity that is clearly defined because they have their own language, history, territory, teaching, and forms of governance (113). Similarly, Kim, another interviewee, explains, "When I think of the word "nation," I think of Oneida...(119)" Through these testimonies Sunseri pushes the boundaries of national discourse to include multi-layered systems of indigenous identity. As a result, Sunseri decolonizes Oneida history by lifting the colonial cultural cloak that often skews or marginalizes indigenous ways of viewing the world. Thus, the Oneida nation is able to exist both within and outside the 